\title{
EFFECTS OF THE TOLUENE AND METHANOL EXTRACT OF SENNA (CASSIA ANGUSTIFOLIA VAHL) ON VIABILITY AND PROLIFERATION HELA CELLS
}

\section{AUTHORS}

CORRESPONDENT

Nedeljko Manojlović

Faculty of Medical Sciences, Kragujevac Republic of Serbia

mtnedeljko@yahoo.com

Rančić A. ${ }^{1}$, Tomović J. ${ }^{2}$, Vasiljević P. ${ }^{3}$, Aleksić M. ${ }^{3}$, Jušković M. ${ }^{3}$, Najman S. ${ }^{3}$, Manojlović N..$^{{ }^{*}}$

${ }^{1}$ Institute of Public Health Kragujevac, 34000 Kragujevac, Serbia

${ }^{2}$ Faculty of Medical Sciences, University of Kragujevac, Kragujevac, Serbia

${ }^{3}$ Faculty of Science and Mathematics, University of Niš, Niš, Serbia

\section{SUMMARY}

Senna (Cassia angustifolia Vahl.) is used in food and pharmaceutical technologies as officinal drugs and natural laxative. The aim of the study was to investigate the effect of toluene and methanol Senna extracts on the viability and proliferation of HeLa cells. The senna leaves were extracted in Soxhlet's extractor and obtained toluene and methanolic extracts were used for determination of effects on viability and proliferation. Cytotoxic effect of different concentrations $(0.1 \%$, $0.01 \%, 0.001 \%$ and $0.0001 \%$ ) extracts was investigated in HeLa cells in vitro. MTT test showed significant cytotoxic activity for toluene extract, especially the concentration of $0.1 \%$, while the tested concentrations metanolic extract did not show cytotoxic activity.

Key words: Cassia angustifolia, viability, proliferation, HeLa cell, MTT, cytotoxic activity.

\section{SRPSKI}

\section{EFEKAT TOLUENSKOG I METANOLSKOG EKSTRAKTA SENE (CASSIA ANGUSTIFOLIA VAHL) NA VIJABILNOST I PROLIFERACIJU}

Rančić A. ${ }^{1}$, Tomović J. ${ }^{2}$, Vasiljević P. ${ }^{3}$, Aleksić M. ${ }^{3}$, Jušković M. ${ }^{3}$, Najman S. ${ }^{3}$, Manojlović N. ${ }^{2 *}$

${ }^{1}$ Institut za javno zdravlje Kragujevac, 34000 Kragujevac, Srbija

${ }^{2}$ Fakultet Medicinskih Nauka, Univerzitet u Kragujevcu, 34000 Kragujevac, Srbija

${ }^{3}$ Prirodno-matematčki fakultet, Univerzitet u Nišu, 18000 Niš, Srbija

\section{SAŽETAK}

List sene (Cassia angustifolia Vahl.) se koristi u prehrambenoj i farmaceutskoj tehologiji kao oficinalna droga i prirodni laksativ. Cilj studije je ispitati efekte toluenskog i metanolskog ekstrakta Sene na vijabilnost i proliferaciju HeLa celija. Ekstrakcijom lišća sene sa Soxhlet-ovim ekstraktorom dobijeni su toluenski i metanolski ekstrakti, koji su korišćeni za ispitivanje efekta na vijabilnost i proliferaciju. Citotoksični efekt različitih koncentacija $(0,1 \%, 0,01 \%, 0,001 \%$ i $0,0001 \%)$ ekstrakata ispitivan je na HeLa ćelijama u in vitro uslovima. MTT test pokazuje visoku citotoksičnost toluenskog ekstrakta, naročito onog koncentracije $0,1 \%$, dok ispitivane koncentracije metanolskog ekstrakta ne pokazuju citotoksičnost.

Ključne reči: Cassia angustifolia, vijabilnost, proliferacija, HeLa ćelije, MTT, citotoksična aktivnost.

\section{INTRODUCTION}

In recent years, interest in studying the different extracts of traditional medicinal plants as a source of potential cytotoxic activity has been increasing [1,2]. Cassia genus belongs to the family Fabaceae (also called Legumino- sae), includes over 700 species which because of therapeutic efficacy are used in medicinal purposes $[3,4,5]$. Cassia L. and Senna Mill. are commonly used medicinal plants for a broad range of diseases and conditions including constipation, parasitic skin diseases, hypercholesterolemia, hypertension, inflammation, pain relief, and antiplatelet aggregating activity $[4,5,6]$. Cassia angustifolia is a plant widespread in tropical regions of East Africa and Asia, where it 
grows as a bush which reaches height of $300 \mathrm{~cm}$ [4]. The drug consists of dried leaves of Senna [7]. Cassia angustifolia is used more than the other species of the genus Cassia because the drug is purer, more homogeneous and more stable composition. The mechanism of action of sennosides is well studied. Sennosides pass through the stomach and small intestine unchanged. They are activated only in the large intestine under the action of bacterial enzymes that hydrolyze them and reduce their active form $[8,9]$. Previous studies of active components from Senna leaves were investigate the genotoxic effects on normal cell lines [10]. The sennosides, main active metabolite of Senna, show a very low toxicity in rats and low genotoxicity in bacterial strains $[6,9,10]$. The laxative property of Senna is based on two glycosides sennoside $A$ and sennoside $B$ [11]. The strongest laxative sennosides $A$ and $B$, shows the lowest toxicity, while fraction that contains rhein 8-glycoside with a minimum efficiency laxative, has increased toxicity $[12,13]$. Emodin and aloe-emodin showed toxic effects on Salmonella typhimurium, on hepatocytes and fibroblasts from mouse [14]. In other studies, such an effect has not been confirmed. In research carried out by Mori mice were treated with $1 \%$ hydroxyanthraquinone 480 days, there were neoplasms in the stomach, liver and intestine $[15,16]$. Sieger and Abendroth in there works show that there is a specifed risk factor in chronic use of laxatives [17,18]. All other tests which were performed did not provide convincing evidence that chronic use of Senna causes functional and structural effects in the body [19].

\section{STYDY OBJECTIVE}

The aim of the study was to investigate the effect of toluene and methanol Senna extracts (Cassia angistifolia Vahl) on the viability and proliferation of HeLa cells.

\section{MATERIAL AND METHODS}

Cells. The extracts were tested on the human cervical carcinoma cell line - HeLa. Cells were cultured in Dulbecco's Modified Eagle's Minimal Essential Medium (DMEM, PAA Laboratories $\mathrm{GmbH}$ ) with supplements of $2 \mathrm{mM} \mathrm{L}$-glutamine, $100 \mu \mathrm{g} / \mathrm{ml}$ streptomycin, 100 units $/ \mathrm{ml}$ penicillin and $10 \%$ fetal bovine serum.

Extracts. Toluen and methanol $(\mathrm{MeOH})$ extracts of Senna (Cassia angustifolia) were prepared by extracting finely milled plant leaves in a Soxhlet extractor for 3 hours. After that, the extract was evaporated under reduced pressure in a vacuum evaporator. The toluen and methanol extracts, obtained in this way, were diluted with enriched DMEM up to final concentrations of $0.0001 \%, 0.001 \%, 0.01 \%$ and $0.1 \%(\mathrm{v} / \mathrm{v})$.

MTT test. The MTT test is a widely accepted method for the rapid and accurate testing of the cytotoxicity of various materials, as well as of cell viability and cell proliferation. This method is based on the capacity of the mitochondrial dehydrogenase of viable cells to reduce tetrazolium salts and create colored formazan products. The number of living cells is directly proportional to the quantity of generated formazan.

Effects on cell viability. HeLa cells were seeded in a 96-well plate for cultivation. In order to determine the effect of Senna extract on the growth of HeLa cells, there were seeded $10^{5}$ cells in each well. The cells were incubated for 24 hours. After incubation, the medium was replaced with methanol and toluene extracts in different concetration. Saponin (with a concentration of $2 \mathrm{mg} / \mathrm{ml}$ ) was used as a positive control. The negative control consisted in cells growing in pure DMEM. It was done in triplicate. The cells were incubated for 24 hours in an atmosphere saturated with water vapor, with $5 \%$ of $\mathrm{CO}_{2}$ at $37^{\circ} \mathrm{C}$. (Jouan, EG 110IR)

Effects on cell proliferation. In order to determine the effect of Senna extract on the proliferation of HeLa cells, $10^{4}$ cells were seeded in the wells. After 24 hours, Senna extract was added. Cisplatine (with a concentration of $6 \mathrm{x}$ $10^{-4} \mathrm{mg} / \mathrm{ml}$ ) was used as a positive control. The cells were incubated for 72 hours in an atmosphere saturated with water vapor, with $5 \%$ of $\mathrm{CO}_{2}$ at $37{ }^{\circ} \mathrm{C}$. It was done in triplicate.

Upon completion of the incubation, the medium was extracted, the cells were washed with $100 \mu \mathrm{l}$ of PBS and there was added a quantity of $20 \mu \mathrm{l}$ of MTT [3- $(4,5-$ dimethylthiazol-2) -2,5-diphenyltetrazolium bromide]. After 4 hours of incubation at $37^{\circ} \mathrm{C}$, the MTT was removed and $100 \mu \mathrm{l}$ of isopropanol were added, in order to dissolve the formed formazan crystals. The spectrophotometric measurement of MTT reduction was carried out at $540 \mathrm{~nm}$, on multi-channel photometer Multiscan Ascent No354, Thermo Labsystems, Finland.

The viability/proliferation percentage of HeLa cells was obtained on the basis of the following formula:

$\%$ Viability (proliferation) = average value of absorbance of each test extracts / average value of control absorbance

\section{RESULTS}

Effects of the toluene and methanol extract of Senna after incubation for 24 hours. Figure 1 shows that cell viability ranges between $23.64 \%$ and $89.98 \%$, after 24 hours of incubation with toluene extract of Senna. The 0.1\% toluene extract of Senna shows the largest decrease in the viability of HeLa cells (23.64\%), while the extract with a concentration of $0.01 \%$ shows the weakest effect on cell viability $(89.98 \%)$. The viability of the cells with methanol extracts, after 24 hours of incubation is in the range of $70.7 \%$ to $101.94 \%$. The lowest viability of HeLa cells was manifested $\mathrm{MeOH}$ extract concentrations of $0.0001 \%$. The concentration of $0.001 \%$ and $0.01 \%$ were showed approximately the same effect on the viability of HeLa cells and which was around $100 \%$. The viability of the HeLa cells at a concentration of $0.1 \%$ of $\mathrm{MeOH}$ extracts was $93.9 \%$. The results do not indicate the existence of a dose relationship between the concentration of methanol extracts of Cassia angustifolia and cell viability. HeLa cell viability at a concentration of $0.0001 \%$ of the extract is $70.70 \%$, which suggested that there was a slight cytotoxic effect. Other concentrations of $\mathrm{MeOH}$ extract did not have cytotoxic effect on the cells during the incubation period of 24 hours. The cell viability with the saponin was $17.7 \%$ 


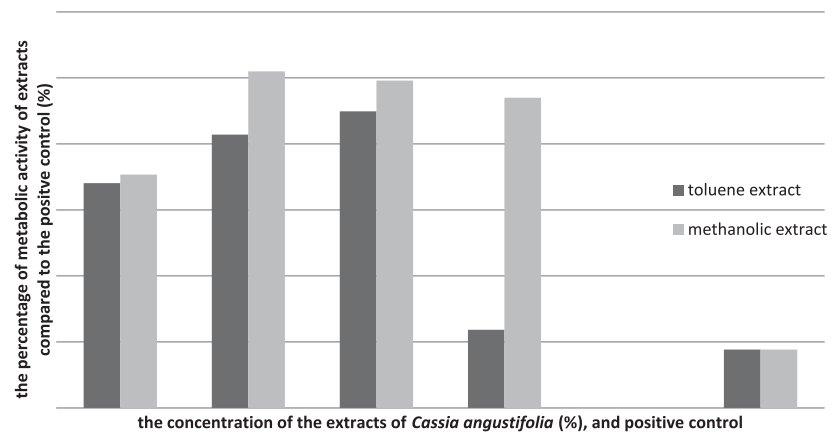

Figure 1. The percentage of the metabolic activity in the HeLa cells compared to the positive control after incubation for 24 hours with different concentrations of toluene and methanol extract of species Cassia angustifolia

Effects of the toluene and methanol extract of Senna after incubation for 72 hours. Figure 2 shows the viability of HeLa cells in the presence toluene extract of Senna after 72 hours of incubation. The viability of HeLa cells ranges between $71.10 \%$ and $101.51 \%$. The highest reduction of cell proliferation $(28.9 \%)$ occurs when the concentration of the toluene extract is $0.0001 \%$. All other toluene extracts showed little effect on cell proliferation, while a $0.001 \%$ concentration showed an increase in the viability of HeLa cells by $1 \%$ in comparison to the negative control. The viability of the cells with methanol extracts, after 72 hours of incubation is in the range of $77.73 \%$ to $131.95 \%$. $\mathrm{MeOH}$ extract with a concentration of $0.0001 \%$ displayed the greatest effect on the reduction of cell proliferation, while cell viability was $77.74 \%$. Concentrations of $0.001 \%$ and $0.01 \%$ showed an increase in the viability of HeLa cells by about $130 \%$, indicating that the given concentrations of Senna had a pronounced proliferative effect. When the concentration of the $\mathrm{MeOH}$ extract of Senna was $0.1 \%$, cell viability amounted to $92.06 \%$, displaying a slight suppression of cell proliferation in comparison to the control group.

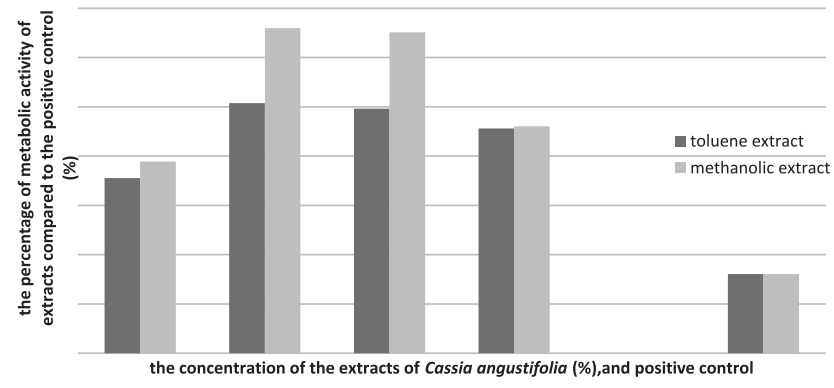

Figure 2. The percentage of the metabolic activity in the HeLa cells compared to the positive control after incubation for 72 hours with different concentrations of toluene and methanol extract of species Cassia angustifolia

\section{DISCUSSION}

The results, after incubation of 24 hours with a toluene extract showed an inhibitory effect on cell viability. The greatest degree of influence had the highest concentration $(0.1 \%)$. A concentration of $0.0001 \%$ to $0.01 \%$ showed a smaller cytotoxic effect than the maximum concentration. Based on the results, which were obtained after 24 hours of incubation HeLa cells with methanol extracts of Cassia angustifolia can be concluded that with increasing conce-ntration of $0.0001 \%$ to $0.01 \%$ increases cell viability, and then at a concentration of $0.1 \%$ fell again $[2,6,10]$.

The results obtained for both extracts indicate that there was no dose dependence between the concentration of Senna extracts and cell viability. By comparing the different concentrations of the tested extracts, it is evident that extracts with middle concentrations had the best effect on the viability and proliferation of HeLa cells. By comparing the results of different types of extracts, we can see that the toluene extract of Cassia angustifolia had a higher inhibitory effect on the viability and proliferation of HeLa cells, unlike methanol, which has a stimulating effect in certain concentrations. The results obtained in this study should be considered as the consequence of the effects of various chemical compounds. The presence of chemical compounds in the extract depended on the solvent that was used. In addition to that, the incubation process lead to the interaction of the compounds in the extract, as well as to the interaction with their metabolic products, which may have had first an inhibitory effect and later a stimulatory effect on cells at certain extract concentrations[12,13].

\section{CONCLUSION}

After analyzing the impact of toluene and methanol extract of Cassia angustifolia on the viability of HeLa cells, we can conclude the following: Toluene extract with a concentration of $0.1 \%$ displayed a high cytotoxicity after 24 hours of incubation, while extracts with lower concentrations were slightly cytotoxic. After 72 hours of incubation, the tested toluene extracts did not inhibit the growth of cells. The tested methanol extracts displayed no cytotoxicity, except in the case of the lowest concentration, which exhibited low cytotoxicity and cytostaticity. Different (toluene and a methanol) extracts of the same plant species have different effects on the viability and proliferation of HeLa cells. The results could contribute to further research and finding new use of Senna, in order to extend the therapeutic indication and use of the chemotherapy but also the treatment of conditions which may find application.

\section{ACKNOWLEDGEMENTS}

The authors acknowledge the financial support of the Ministry of Education, Science and Technology of the Republic of Serbia (Grants No. 172047 and 172015). 


\section{REFERENCES}

1. Gordanian B, Behbahani M, Carapetian J, Fazilati M. In vitro evaluation of cytotoxic activity of flower, leaf, stem and root extracts of five Artemisia species. Research in Pharmaceutical Scinces, 2014; 9(2): 91-96.

2. Kamal H, Musfizur H, Nazma P, Mahmudul H, Siddiqul I, Ahsanul H. Antimicrobial, cytotoxic and thrombolytic activity of Cassia senna leaves. Journal of Applied Pharmaceutical Science, 2012; 02(06): 186-190.

3. Sultana S, Ahmad M, Zafar M, Khan A, Arshad M. Authentication of herbal drug Senna (Cassia angustifolia Vahl.): A village pha-rmacy for Indo-Pak Subcontinent. African journal of pharmacy and pharmacology, 2012; 6(30): 2299-2308.

4. Seethapathy GS, Ganesh D, Kumar S, Senthilkumar U, Newmaster SG, Ragupathy S, Shaanker RU, Ravikanth G. Assessing pro-duct adulteration in natural health products for laxative yielding plants, Cassia, Senna, and Chamaecrista, in Southern India using DNA barcoding. International Journal of Legal Medicine, 2014; DOI 10.1007/s00414-014-1120-z.

5. Monkheang P, Sudmoon R, Tanee T, Noikotr K, Bletter N, Chaveerach A. Species diversity, usages, molecular markers and barcode of medicinal Senna species (Fabaceae, Caesalpinioideae) in Thailand. Journal of Medicinal Plants Research, 2011; 5(26): 6073-6181.

6. Silva CR, Monteiro MR, Rocha HM, Ribeiro AF, Caldeira-de-Araujo A, Leitão AC,. Bezerra R, Pádula M. Assessment of antimutagenic and genotoxic potential of senna (Cassia angustifolia Vahl.) aqueous extract using in vitro assays. Toxicology in Vitro, 2008; 22(1): 212-218

7. Satywanti GV. Medicinal Plants of India; ICMR: New Delhi, India. 1976; 1: 197.

8. Chatterjee A, Pakrashi SC. The Treatise of Indian Medicinal Plants; PID, CSIR New Delhi 1992; 2: 35-41.

9. Upadhyay A, Chandel Y, Nayak PS, Khan NA. Sennoside contents in Senna (Cassia angustifolia Vahl.) as influenced by date of leaf picking, packaging material and storage period. Journal of stored products and postharvest research, 2011; 2(5): 97103.

10. Hietala P, Marvola M, Parviainen T, Lainonen H. Laxative potency and acute toxicity of some anthraquinone derivatives, senna extracts and fractions of senna extracts. Pharmacology and Toxicology, 1987; 61(2): 153-156.

11. Yamasaki K, Kawaguchi M, Tagami T, Sawabe Y, Satoshi Takatori. Simple and rapid analysis of sennoside A and sennoside B contained in crude drugs and crude drug products by solid-phase extraction and high-performance liquid chromatography. Journal of Natural Medicines, 2010; 64(2): 126-132.

12. Mengs U, Mitchell J, McPherson M, Gregson R, Tigner J. A 13-week oral toxicity study of senna in the rat withan 8-week recovery period. Archives of Toxicology, 2004; 78(5): 269 -275.

13. Mitchell JM, Mengs U, McPherson S. Anoralcarcinogenicity and toxicity study of senna (Tinnevelly senna fruits) intherat. Archives of Toxicology 2006. (80):34-44

14. Sandnes D, Johansen T, Teien G, Ulsaker G. (1992) Mutagenicity of crude senna and senna glycosides in Salmonella typhimurium. Pharmacology and Toxicology, 1992; 71(3): 165-172.

15. Mori H, Yoshimi N, Iwata H. Carcinogenicity of naturally occurring 1-hydroxyanthraquinone in rats: induction of large bowel, liver and stomach neoplasms. Carcinogenesis, 1990; 11(5): 799-802.

16. Nusko G, Schneider B, Schneider I, Wittekind Ch, Hahn EG. Anthranoid laxative use is not a risk factor for colorectal neoplasia: results of a prospective case control study. Gut, 2000; 46(5) :651-655.

17. Siegers CP, Von Hertzberg-Lotton E, Otte M, Schneider B. Anthranoid laxative abuse - a risk for colorectal cancer?Gut, 1993; 34(8): 1099-1101.

18. Abendroth A, Klein R, Schlaak J, Metz KA, Dobos GJ, Langhorst J. Impressive picture of a melanosis coli afterchronicanthraquinonelaxativeuse--is there an increased risk for colorectal cancer? Z Gastroenterol, 2009; 47(6): 579-582.

19. Westendorf J, Marquardt H, Poginsky B, Dominiak M, Schmidt J, Marquardt H. Genotoxicity of naturally occurring hydroxyanthraquinones. Mutation Research, 1990; 240 (1): 1-12. 